\title{
PEMBERIAN KUIS DI AWAL PEMBELAJARAN UNTUK MENINGKATKAN KESIAPAN DAN HASIL BELAJAR SISWA KELAS X MIPA
}

\author{
I Komang Trisna, ${ }^{1 *}$, I Wayan Subagia, Putu Oka Herawati \\ ${ }^{1}$ Universitas Pendidikan Ganesha \\ 2Universitas Pendidikan Ganesha \\ ${ }^{3}$ SMA Negeri 1 Singaraja
}

\begin{abstract}
Abstrak
Hasil observasi awal pada pembelajaran dengan sub topik bahasan ikatan ion menunjukkan bahwa partisipasi siswa dalam mengikuti pembelajaran sangat rendah. Selain itu, hasil pengerjaan kuis di awal pembelajaran menunjukkan persentase ketuntasan sebesar 17,86\% dengan rata-rata nilai 21,79. Hasil tersebut mengindikasikan rendahnya kesiapan dan hasil belajar siswa. Untuk mengatasi permasalahan tersebut maka diajukan solusi berupa pemberian kuis di awal pembelajaran untuk meningkatkan kesiapan dan hasil belajar siswa kelas X MIPA 5 SMA Negeri 1 Singaraja tahun ajaran 2016/2017. Jenis penelitian yang dilakukan adalan penelitian tindakan kelas (PTK). Tempat pelaksaan penelitian ini adalah di SMA Negeri 1 Singaraja pada bulan September sampai dengan bulan November tahun 2016. Subyek dari penelitian ini adalah seluruh siswa kelas X MIPA 5, sedangkan obyek penelitian ini adalah kesiapan dan hasil belajar siswa. Penelitian ini dilakukan dalam 2 siklus dengan rincian satu siklus terdiri dari satu kali pertemuan. Data yang dikumpulkan berupa data kuantitatif yaitu hasil pengerjaan kuis di awal pembelajaran setiap siklus dan hasil pengerjaan tes hasil belajar. Data yang diperoleh disajikan secara deskriptif dan dianalisis secara kualitatif berdasarkan kriteria ketuntasan klasikal (KK). Hasil analisis data dari observasi awal sampai dengan siklus II menjunjukkan adanya peningkatan persentase ketuntasan dan rata-rata nilai siswa dalam mengerjakan soal kuis di awal pembelajaran. Persentase ketuntasan pengerjaan soal kuis pada observasi awal sebesar $17,86 \%$ dengan rata-rata nilai 21,79 , meningkat menjadi $34,48 \%$ dengan rata-rata nilai 58,28 pada siklus I dan menjadi $72 \%$ dengan rata-rata nilai 80,60 pada siklus II. Hasil pengerjaan tes hasil belajar menunjukkan ketuntasan sebesar $80 \%$ dengan rata-rata nilai 79,59. Data yang diperoleh menunjukkan bahwa metode pemberian kuis di awal pembelajaran efektif dalam meningkatkan kesiapan dan hasil belajar siswa XI MIPA 5 SMA Negeri 1 Singaraja Tahun Ajaran $2016 / 2017$.
\end{abstract}

Kata-kata kunci:

kuis, kesiapan belajar, dan hasil belajar

\section{Pendahuluan}

SMA Negeri 1 Singaraja adalah salah satu SMA yang terletak di kabupaten Buleleng. Sekolah ini termasuk ke dalam jajaran sekolah unggulan yang terdapat di provinsi Bali. Hal ini dibuktikan dengan banyaknya gelar juara yang diperoleh oleh siswa SMA Negeri 1 Singaraja pada bidang akademik maupun non-akademik, baik pada tingkat kabupaten, provinsi, nasional, maupun internasional. Keberhasilan SMA Negeri 1 Singaraja tidak terlepas dari kualitas input siswa dan proses pembelajaran yang bermutu. Pembelajaran di SMA Negeri 1 Singaraja berlangsung menggunakan kurikulum tahun 2013 dan secara umum dalam pelaksanaanya sudah berjalan dengan optimal. Berdasarkan observasi yang penulis lakukan di kelas X MIPA 5 SMA Negeri 1 Singaraja, dapat dilihat bahwa kegiatan pembelajaran berlangsung dengan lancar. Kelas X MIPA 5 terdiri atas 13 siswa laki-laki dan 17 siswa perempuan. Jumlah siswa yang relatif sedikit secara tidak langsung mempermudah guru dalam mengelola kegiatan belajar mengajar. Namun, dari observasi peneliti menemukan beberapa permasalah yang menyebabkan pembelajaran di kelas tidak optimal.

Beberapa permasalahan yang peneliti jumpai dalam proses pembelajaran meliputi rendahnya 
partisipasi siswa dalam pembelajaran. Rendahnya partisipasi siswa terlihat dari rendahnya kuantitas siswa dalam mengajukan diri untuk menjawab pertanyaan guru maupun mengajukan pertanyaan. Selain itu, jika dilihat dari kualitas jawaban dan pertanyaan siswa bisa dikatakan masih relatif rendah. Hal tersebut tercermin dari jawaban serta pertanyaan siswa yang sebagian besar keliru dan melenceng dari materi yang sedang dibahas. Selain masalah di atas juga ditemukan beberapa fenomena, yaitu; a) siswa kebingungan mencari meteri di buku pelajaran ketika diberikan pertanyaan oleh guru; b) siswa tidak mengetahui materi yang akan dipelajari pada saat proses pembelajaran di kelas; c) beberapa siswa sibuk mengerjakan tugas mata pelajaran lain, mengobrol dan bahkan membolos pada waktu pembelajaran di kelas berlangsung; serta d) dalam mengerjakan LKS siswa mencontek pekerjaan kelompok lainya. Rendahnya partisipasi siswa di kelas menunjukkan bahwa persiapan yang dilakukan siswa sebelum pembelajaran di kelas relatif rendah. Kesiapan belajar merupakan hal yang mendasar yang harus ada dalam diri seorang siswa untuk mengikuti pembelajaran di kelas. Slameto (2003) menyatakan kesiapan adalah keseluruhan semua kondisi individu yang siap membuatnya siap untuk memberi respon atau jawaban dalam cara tertentu terhadap suatu situasi. Rendahnya kesiapan dan hasil belajar siswa sangat terlihat jelas pada persentase ketuntasan siswa dalam mengerjakan kuis di awal pembelajaran pada sub pokok bahasan ikatan ion. Adapun ketuntasan siswa dalam mengerjakan soal kuis sub pokok bahasan ikatan ion adalah sebesar $17,86 \%$ dengan rata-rata nilai 21,79. Melihat permasalahan di atas, maka pemberian kuis di awal pembelajaran diharapkan mampu meningkatkan kesiapan dan hasil belajar siswa. Kesiapan belajar tentunya akan berpengaruh pada kualitas pembelajaran di kelas. Adanya kesiapan yang baik akan meningkatkan motivasi siswa dalam mengikuti pembelajaran di kelas, sehingga pembelajaran yang dilakukan siswa di kelas akan lebih efektif dan bermakna. Peningkatan kualitas proses pembelajaran ini nantinya akan berpengaruh langsung pada hasil belajar siswa. Oleh karena itu, kesiapan belajar siswa sebelum mengikuti pembelajaran sangat penting untuk diperhatikan demi optimalnya proses pembelajaran dan perolehan hasil belajar siswa. Berdasarkan latar belakang di atas, peneliti tertarik mengadakan yaitu: kriteria keberhasilan peningkatan kesiapan belajar siswa dan kriteria keberhasilan hasil belajar siswa. Kriteria keberhasilan peningkatan kesiapan belajar siswa berupa peningkatan ketuntasan nilai kuis secara klasikal penelitian untuk meningkatkan kesiapan dan hasil belajar siswa melalui metode pemberian kuis di awal pembelajaran pada siswa kelas $\mathrm{X}$ MIPA 5 SMA Negeri 1 Singaraja tahun ajaran $2016 / 2017$.

\section{Metode}

Penelitian ini merupakan penelitian tindakan kelas (classroom action research). Secara singkat PTK dapat didefinisikan sebagai suatu bentuk penelaahan penelitian yang bersifat reflektif dengan melakukan tindakantindakan tertentu agar dapat memperbaiki dan meningkatkan praktik-praktik pembelajaran di kelas secara lebih profesional.

Penelitian tindakan dilaksanakan dalam kawasan kelas dengan tujuan untuk memperbaiki dan meningkatkan kesiapan dan hasil belajar siswa melalui pemberian kuis di awal pembelajaran. Penelitian ini dibagi menjadi 2 (dua) kegiatan yaitu refleksi awal dan pelaksanaan tindakan. Penelitian ini berlangsung dalam dua siklus, masing-masing siklus terdiri dari empat tahapan yaitu: (1) perencanaan, (2) pelaksanaan, (3) observasi/evaluasi, dan (4) refleksi. Desain penelitian dapat digambarkan sebagai berikut. Jenis data yang digunakan dalam penelitian ini adalah data kuantitatif. Data kesiapan siswa dihimpun menggunakan soal kuis, sedangkan data hasil belajar dihimpun mengunakan soal tes hasil belajar. Berikut disajikan tabel jenis data, sumber data, dan instrumen untuk penelitian tindakan kelas yang dilakukan.

Data yang diperoleh dalam penelitian ini adalah data kuantitatif yang disajikan secara deskriptif dan dianalisis secara kualitatif sesuai dengan jenis dan kegunaannya dalam penelitian. Data kuantitatif pada penelitian ini adalah nilai yang diperoleh siswa dalam mengerjakan soal kuis dan soal tes hasil belajar.

Ketuntasan siswa dapat ditentukan dengan menggunakan kriteria ketuntasan klasikal (KK). Adapun perhitungan ketuntasan klasikal adalah sebagai berikut.

$$
\mathrm{KK}=\frac{\text { Banyak siswa yang tuntas }}{\text { Banyak siswa yang ikut tes }} \times 100 \%
$$

Penelitian tindakan kelas ini memiliki tujuan umum untuk meningkatkan kesiapan dan hasil belajar siswa dengan perlakuan berupa pemberian kuis di awal pembelajaran. Pada penelitian ini terdapat dua kriteria keberhasilan,

sebesar 15\% dari siklus I ke siklus II. Sedangkan kriteria keberhasilan peningkatan hasil belajar berupa ketuntasan nilai hasil belajar secara klasikal di atas $70 \%$. Siswa dinyatakan tuntas jika nilai yang diperoleh dalam mengerjakan soal 
kuis maupun tes hasil belajar di atas kriteria ketuntasan minimum (KKM) yaitu 75 .

\section{Pembahasan}

Berdasarkan penelitian yang telah dilaksanakan selama dua siklus di kelas X MIPA 5 SMA Negeri 1 Singaraja tahun pelajaran $2016 / 2017$ pada semester ganjil, maka didapatkan hasil penelitian yang menunjukkan adanya peningkatan kesiapan dan hasil belajar siswa melalui pemberian kuis di awal proses pembelajaran.

Hasil kuis pada observasi awal menunjukkan bahwa persentase ketuntasan siswa sebesar $17,86 \%$ dengan rata-rata nilai sebesar 21,79. Hal tersebut menunjukkan bahwa sebelum dilakukan tindakan kesiapan siswa tergolong sangat rendah. Berdasarkan data yang diperoleh diketahui dari 28 siswa yang hadir, hanya 5 orang yang mendapatkan nilai di atas kriteria ketuntasan minimal yaitu 75. Data yang diperoleh menjadi gambaran awal yang jelas terkait rendahnya kesiapan belajar siswa.

Berdasarkan gambaran observasi awal maka dilakukan perencanaan untuk siklus I. Berdasarkan hasil pengerjaan soal kuis pada siklus I, diketahui bahwa persentase ketuntasan siswa sebesar $17,86 \%$ dengan rata-rata nilai sebesar 58,28. Rata-rata nilai siswa yang masih berada di bawah KKM menunjukkan bahwa kesiapan relatif rendah. Berdasarkan data yang diperoleh, diketahui dari 29 siswa yang hadir hanya 10 orang yang mendapatkan nilai di atas kriteria ketuntasan minimal. Hasil tersebut menunjukkan bahwa kesiapan belajar siswa pada siklus I masih tergolong rendah, walaupun terdapat peningkatan presentase ketuntasan dan rata-rata nilai dibandingkan observasi awal. Masih rendahnya kesiapan belajar siswa pada siklus I disebabkan oleh beberapa kendala dan permasalahan yang telah diuraikan pada hasil refleksi pada siklus I.

Perbaikan yang dilakukan terhadap beberapa kendala dan permasalahan yang dihadapi telah dipaparkan pada perencanaan siklus II. Berdasarkan perbaikan tindakan yang telah dilakukan pada siklus II, diperoleh persentase ketuntasan siswa sebesar 72\% dengan rata-rata nilai 80,60. Jika dibandingkan dengan hasil siklus I, dapat dilihat bahwa pada siklus II terjadi peningkatan persentase ketuntasan sebesar $37,52 \%$ dan rata-rata nilai sebesar 22,32. Berdasarkan data yang diperoleh, diketahui dari 25 siswa yang hadir terdapat 18 orang yang mendapatkan nilai di atas kriteria ketuntasan minimal. Hasil tersebut menunjukkan terdapat peningkatan kesiapan belajar siswa dari observasi awal menuju siklus II. Selain itu, rata-rata nilai siswa yang berada di atas KKM menunjukkan bahwa kesiapan belajar siswa pada siklus II sudah tergolong baik.

Disamping peningkatan persentase ketuntasan dan nilai rata-rata, pada akhir siklus II juga dilaksanakan tes hasil belajar. Perolehan nilai siswa dalam mengerjakan tes hasil belajar menunjukkan persentase ketuntasan siswa adalah sebesar $80 \%$ dengan rata-rata nilai sebesar 79,59. Hal ini menunjukkan bahwa pemberian kuis di awal pembelajaran berpengaruh langsung terhadap hasil belajar siswa.

Pada penelitian ini, kesiapan belajar siswa dilihat dari aspek persentase ketuntasan dalam mengerjakan kuis di setiap siklus, sedangkan hasil belajar dilihat dari aspek persentase ketuntasan siswa dalam mengerjakan tes hasil belajar yang diukur pada akhir siklus II. Berdasarkan hasil penelitian, diperoleh bahwa peningkatan persentase ketuntasan siswa dalam mengerjakan soal kuis dari siklus I ke siklus II yaitu sebesar 37,52\% lebih besar daripada kriteria keberhasilan yang telah ditetapkan sebelumnya yaitu sebesar $15 \%$. Selain itu, dari pengerjaan tes hasil belajar diperoleh bahwa persentase ketuntasan sebesar $80 \%$ lebih besar daripada kriteria keberhasilan yang ditetapkan sebelumnya yaitu sebesar 70\%. Hasil tersebut menunjukkan bahwa penelitian tindakan kelas yang dilakukan sudah mampu mengatasi permasalah terkait rendahnya kesiapan dan hasil belajar siswa. Tercapainya kriteria keberhasilan sekaligus menandakan bahwa tindakan siklus II tidak dilanjutnya ke siklus III.

Peningkatan kesiapan dan hasil belajar siswa kelas X MIPA 5 SMA Negeri 1 Singaraja tentunya tidak terlepas dari pemberian kuis di awal proses pembelajaran. Adanya kuis di awal pembelajaran akan membuat siswa termotivasi untuk belajar di luar kelas, baik dengan membaca buku, mengerjakan soal, maupun berdiskusi dengan teman sekelas atau guru. Siswa yang memiliki kesiapan belajar cenderung memiliki pemahaman yang baik terkait materi prasyarat dan materi yang akan diajarkan di kelas. Hal tersebut akan menumbuhkan motivasi siswa untuk aktif berpartisipasi dalam kegiatan diskusi kelas maupun diskusi kelompok, sehingga pembelajaran akan menjadi lebih bermakna bagi siswa yang bersangkutan. Melalui diskusi, siswa aktif dalam bertukar pikiran dengan sesama temanya dalam memperdalam, maupun menemukan konsep baru. Selain itu, dengan pemahaman awal yang baik akan berpengaruh pada kemampuan siswa dalam menerima materi pelajaran di kelas. Adanya pemaham awal yang baik akan menyebabkan siswa lebih mudah dalam mengkontruksi dan menguatkan penguasaan 
konsepnya melalui pembelajaran di kelas. Yuyaelawati (2004) berpendapat, untuk membangun suatu konsep maka peserta didik akan menyesuaikan informasi baru atau pengetahuan yang disampaikan guru dengan pengetahuan atau pengalaman yang telah dimilikinya melalui berinteraksi sosial dengan peserta didik lainya atau dengan gurunya. Pendapat tersebut juga didukung oleh teori yang dikemukakan Vygotsky (dalam Slavin, 2005), yang menyatakan bahwa fungsi kognitif manusia berasal dari interaksi sosial masing-masing individu dalam konteks budaya.

Secara umum, dengan kebiasan mempersiapkan diri sebelum pembelajaran telah membawa siswa pada pembelajaran yang student-centered. Siswa secara aktif mengkontruksi pemahamanya di luar kelas maupun di dalam kelas tanpa menunggu informasi dari guru. Hal ini didukung pendapat Vygotsky (Slavin, 1995), yang menyatakan bahwa siswa membentuk pengetahuan, yaitu apa yang diketahui siswa bukanlah peniruan dari apa yang mereka temukan di dalam lingkungan, tetapi sebagai hasil dari pikiran dan kegiatan siswa sendiri melalui bahasa. Adapun penguasaan konsep yang dimiliki siswa bersifat tahan lama, karena konsep ditemukan sendiri oleh siswa berdasarkan interaksinya dengan teman kelompoknya serta sumber belajar. Guru dalam pembelajaran hanya bertugas menjadi fasilitator dalam pembelajaran seperti yang diharapkan oleh paradigma pembelajaran modern.

Kesiapan belajar yang baik akan memotivasi siswa dalam mengikuti pembelajaran di kelas, sehingga akan mengoptimalkan kualitas pembelajaran di kelas. Hal tersebut secara langsung akan berpengaruh pada hasil belajar siswa. Hal ini didukung oleh hasil penelitian yang dilakukan oleh Bernadeta Ayu Setyanta dan Enny Murwaningtyas (2012) yang menunjukkan bahwa pemberian kuis berpengaruh positif terhadap motivasi dan hasil belajar siswa. Hal yang sama juga ditemukan dari hasil penelitian yang dilakukan oleh Ariffatin (2010) mengenai pemberian kuis yang berpengaruh positif terhadap motivasi dan prestasi belajar siswa. Selain itu, kuis yang diberikan secara kontinu dapat meningkatkan prestasi belajar sebab pada umumnya siswa akan berusaha aktif dan belajar lebih tekun untuk mendapatkan nilai yang baik. Hal ini sesuai dengan pendapat Ahmad (1990) yang menyatakan bahwa tes yang sering diadakan dapat meningkatkan prestasi belajar siswa sebab, tes akan mendorong dan mengharuskan mereka belajar lebih teratur, lebih rajin dan lebih tekun. Sadirman (1992) menyatakan bahwa para siswa akan lebih giat belajar kalau mengetahui akan ada kuis. Oleh karena itu memberikan kuis merupakan suatu sarana memotivasi belajar siswa. Berdasarkan pemaparan di atas dapat dikatakan bahwa pemberian kuis berdampak positif pada peningkatan kesiapan dan hasil belajar siswa. Kesiapan belajar yang baik secara langsung akan meningkatkan motivasi siswa dalam mengikuti pembelajaran dan memberikan kemudahan bagi siswa dalam mencerna materi yang disampaikan, sehingga akan berpengaruh pada tingginya hasil belajar siswa.

\section{Penutup}

Berdasarkan hasil penelitian yang diperoleh dan pembahasan, maka dapat diambil simpulan bahwa pemberian kuis di awal pembelajaran dapat meningkatkan kesiapan dan hasil belajar siswa kelas X MIPA 5 SMA Negeri 1 Singaraja tahun ajaran 2016/2017. Hal ini dapat dilihat dari peningkatan persentase ketuntasan siswa dalam mengerjakan kuis dari siklus I dan siklus II. Selain itu, berdasarkan hasil pengerjaan tes hasil belajar diperoleh persentase ketuntasan sebesar $80 \%$ dengan rata-rata nilai sebesar 79,59.

\section{Daftar Pustaka}

Ahmad Rohani. 1990. Pengelola Pengajaran. Jakarta: Reneka Cipta.

Arikunto. 2007. Prosedur Penelitian Suatu Pendekatan Praktik. Jakarta: Rineka Aksara.

Depdiknas. 2006. Kurikulum Tingkat Satuan Pendidikan Sekolah Menengah Atas. Jakarta: Depdiknas.

Dwi Wahyuni. 2005. Pengaruh Kesiapan Belajar, Motivasi Belajar dan Pengulangan Materi Pelajaran Terhadap Hasil Belajar Mata Pelajaran Ekonomi pada Siswa Kelas II MA Al Asror Gunung Pati Tahun Pelajaran 2004/2005. Diakses dari

http://lib.unnes.ac.id/317/1/1038.pdf pada tanggal 26 Agustus 2016.

Nurkancana. 1990. Evaluasi Pendidikan. Surabaya: Usaha Nasional.

Santyasa, I W. 2004. Pengaruh Model Pembelajaran Terhadap Remidiasi, Miskonsepsi, Pemahaman Konsep dan Hasil Belajar Fisika pada Siswa SMU. Disertasi (tidak diterbitkan). Program Studi Teknologi Pembelajaran Pascasarjana, Universitas Negeri Malang

Sardiman, A.M., 1992. Interaksi Motivasi Belajar Mengajar. Jakarta: CV Rajawali.

Slameto. 2003. Belajar dan Faktor-Faktor yang 
Mempengaruhinya. Jakarta: PT Rineka Cipta.

Slavin, R. E. 1995. Cooperative Learning: Theory, Research, and Practice. Second Edition. Boston: Alyn and Bacon

Trianto. 2007. Model-Model Pembelajaran
Inovatif Berorientasi

Konstruktivistik. Jakarta: Prestasi Pustaka Publisher

Yulaelawati, E. 2004. Kurikulum dan Pembelajaran Filosofi Teori dan Aplikasi. Jakarta: Pakar Raya 